\title{
The Designing Model of Sport for All in the Employees of Iranian Universities
}

\author{
${ }^{1}$ Mohammad Mohammadian ${ }^{(D)}$, ${ }^{1}$ Ali Khazaei ${ }^{(D)}$ ", 'Jafar Khodabandeh Lou, \\ ${ }^{1}$ Mohammadkarim Bahadori ${ }^{\mathbb{D}},{ }^{1}$ Mansour Babaei \\ ${ }^{1}$ Health Management Research Center, Baqiyatallah University of Medical Sciences, Tehran, Iran.
}

Submitted 21 July 2020; Accepted in final form 31 January 2021.

\begin{abstract}
Background. Sport for all is considered as one of the sub-indicators of human development in societies because it increases life expectancy by promoting the health of people in society. Objectives. The purpose of this study was the designing model of sport for all in the employees of Iranian universities. Therefore, a model has been designed to develop for military personnel participating in sports for all at Baqiyatallah University. Methods. The method of the present study is qualitative research. This systematic study, which is attributed to Strauss and Corbin (1990), was conducted in three stages of open, axial, and selective coding. Due to the executive nature of the work, for conducting university interviews, the statistical population of the research consisted of elite and expert faculty members, managers, and officials of sports at Baqiyatallah University, who were purposefully selected for qualitative interviews on the subject of research. These specialists were aware and active in various educational, research, and executive departments of the research subject. During a six-month process and conducting in-depth interviews with experts, the researcher reached the point of theoretical saturation and after conducting fourteen interviews, completed the interviews. The results showed that the most important causal factors are: creating a healthy environment, gaining vitality, and maintaining physical fitness. Results. Management factors, official documents, structural factors and socio-cultural factors of the context, media advertising, deterrents as intervening conditions and categories related to strategies, core program, awareness, support, and motivational programs, holding competitions, were promoting active lifestyles and monitoring and evaluation. Conclusion. Finally, the consequences of the organizational outcomes model were individual outcomes that university sports managers are aware of and by taking appropriate measures and planning to remove barriers and create the necessary incentives for staff participation.
\end{abstract}

KEYWORDS: Sports Participation, Sport for All, Employees, University.

\section{INTRODUCTION}

Physical inactivity is a global health problem (1). It causes coronary heart disease, type 2 diabetes, cancer, etc. (2). The workplace can be a sedentary place for many employees, so employees are among those who are exposed to sedentary work patterns (3). Factors that determine participation in sports at work can be influenced by individual needs, motivation, and organizational support (4). From the organizational viewpoint, participating in sports has benefits such as increasing productivity and efficiency (5) and reducing staff absenteeism (6). In the individual dimension, participation in sports plays an essential role in the prevention of physical and mental illness $(7,8)$. For the Armed Forces and its personnel as protectors of the system and security

*. Corresponding Author:

Ali Khazaei, M.Sc.

E-mail: ali.khazaei@atu.ac.ir 
of society, participation in Sport for all is of particular importance. Therefore, maintenance, growth, health and strength of the body is a fundamental issue (9). To achieve these goals, general policies in the Armed Forces are planned around the four main axes of Sport for all, education, championship sports and professional sports (10). Sport for all are an essential part of a community's public health. Having a regular exercise program is also considered as one of the basic components of a healthy working life (11). At least 30 minutes of physical activity a day should be considered a normal part of a worker's life. This amount of physical activity allows the body to achieve the desired physical and mental growth (12). Participation in Sport for all for growth and development requires tools such as economic facilities, development of sports fields, provision of inexpensive sports equipment, publication of sports and health research. Also, planning and management for Sport for all should be comprehensive and include all groups of men and women of different ages. In order to increase public participation, the Sport for all program must be free and sponsored by the organization. In addition, one of the main materials needed for greater employee participation in sports is the expansion of sports facilities, sports training (13). Studies show effective factors in participating in sports, including providing education (14), improving self-efficacy, improving knowledge about physical activity, facilitating goal-setting activities, and strengthening social support through peers and family support (15)). (16), in analyzing the stages of sports training for military personnel, concluded that in the first stage, the interests of employees in the field of sports should be examined. Then the goals of sports education should be defined, and in the last stage of the training process, be planned and implemented by an organized force. (17), in a study also concluded that the scientific and practical development of physical fitness, physical skills and sports to achieve the appropriate level of the specified indicators, promotion of championship sports of the Armed Forces in order to achieve rank Top competitions in domestic and foreign competitions, especially in applied disciplines, strengthening and promoting Sport for all in the Armed Forces is one of the main goals of sports development in the Armed Forces. In the Armed Forces, manpower is the main foundation of this force and special planning for this resource is one of the most important necessary measures in this organization. This in itself can be useful in increasing the combat capability of the armed forces and in achieving the goal of the armed forces (18). Thus, the tendency of military personnel towards sports and the benefits that result from it lead managers and officials to explore ways that increase participation in Sport for all.

Certainly, the cohesive view to these groups will lead to progress in this regard. As these perspectives differ, the lack of coordination between the perspectives challenges the planning work for the development of participation in sport. The development of sports participation in various ways should be considered by the officials of Baqiyatallah University of Medical Sciences. Recognizing the effective factors in the development of sports participation can cause planners to be aware of them and take appropriate measures and planning to remove obstacles. Therefore, in order to determine the factors affecting development in the form of a conceptual model, the researcher intends to analyze a model based on the condition and status of sports of the staff of Baqiyatallah University of Medical Sciences in terms of the effectiveness of each of the factors and dimensions of the development of sports participation. Therefore, in this research, an attempt has been made to meet this scientific and study need for the university.

\section{MATERIALS AND METHODS}

Participants. The nature of this research is exploratory-fundamental and its approach is qualitative, using the foundation's data strategy. In this research, the systematic strategy of Strauss and Corbin (1999) has been used. In the first stage, using a library study and a systematic review of past research in this field, semi-open and semi-closed questions to interview 14 experts in this field (all managers and physical education officials of the university, some University professors, and physical education management experts). According to the principles of sampling in theoretical research, purposive sampling was used. Theoretical sampling continued until the categories reached theoretical saturation.

Data Collection/ Measures. To analyze the collected qualitative data, three steps of open, axial, and selective coding should be performed. Since concepts are the main foundations of theory building, it is necessary to establish a mechanism to identify concepts and expand them according 
to their characteristics and dimensions. This mechanism is performed in open data coding theory; from the raw data, introductory categories related to the phenomenon under study by asking about data, comparing cases, events, and other phenomena to gain similarities and differences were extracted. From the raw data, a set of categories emerged during the open coding.

Analysis. This step includes the steps of analysis and coding, the discovery of categories, description of categories according to their characteristics, and finally, open coding table. In the next step; the main category which is the development of sport for all in this research was explored through axial coding, and then, other categories were theoretically related to it. These categories are: Causal conditions (causes of the formation of the main phenomenon), Interaction strategies (actions or interactions performed to control, manage, deal with, and respond to the underlying phenomenon), Intervention conditions (effective general conditions in strategies), and consequences (the result of applying strategies). In the last stage of coding, because the main components represent their proposed theory or process, the researcher acts more selectively on the basis of these emerging components in coding. Hence, this step is called selective. The researcher's next task is to categorize and compare the concepts extracted from the depth of the data. At this stage, ideas and concepts were placed in the same categories. Finally, the factors for the development of participation in Sport for all of military personnel were identified.

\section{RESULTS}

According to Table 1 most of the participants had a specialized doctoral degree (9 people, $64.3 \%$ ) and most people had experience in the field of Sport for all between 6-10 years (4 people, 28.6\%). Also 9 participants (64.3\%) had executive experience in the university sports department. Other results are shown in Table 1.

Causal Condition. In this section, the reasons for the importance of the main phenomenon of "effective factors for the development of participation in Sport for all" were identified. Five factors extracted from axial coding that made it important to examine the factors that contributed to the development of participation in Sport for all.

Table 1. Demographic Information of the Participants

\begin{tabular}{|c|c|c|}
\hline Demographic characteristics & Abundance & Frequency \\
\hline \multicolumn{3}{|l|}{ Gender } \\
\hline Man & 12 & 85.7 \\
\hline Female & 2 & 14.3 \\
\hline \multicolumn{3}{|l|}{ Education } \\
\hline M.A & 5 & 35.7 \\
\hline P.H.D & 9 & 64.3 \\
\hline \multicolumn{3}{|l|}{ Duration of activity in sports } \\
\hline Less than 5 years & 3 & 21.4 \\
\hline $6-10$ years & 4 & 28.6 \\
\hline $11-15$ years & 3 & 21.4 \\
\hline $16-20$ years & 2 & 14.3 \\
\hline More than 20 years & 2 & 14.3 \\
\hline \multicolumn{3}{|l|}{ Organizational position } \\
\hline Academic & 5 & 35.7 \\
\hline Executive & 9 & 64.3 \\
\hline Total & 14 & $100 \%$ \\
\hline
\end{tabular}

Table 2. Selective, Axial, and Open Coding of Causal Conditions

\begin{tabular}{lc}
\hline Category & Open Code \\
\hline Causal conditions & $\begin{array}{c}\text { Increasing employees' knowledge about the benefits of sports / The role of reference groups } \\
\text { (family) / Teaching the benefits of sports / Paying attention to scientific resources / Changing the } \\
\text { mental approach of employees }\end{array}$ \\
$\begin{array}{l}\text { Increasing awareness } \\
\text { Liveliness and } \\
\text { motivation }\end{array}$ & $\begin{array}{c}\text { Increasing vitality / encouraging sports / strengthening morale / paying attention to employees' } \\
\text { sports interests }\end{array}$ \\
$\begin{array}{c}\text { Increase health } \\
\text { Mhysical fitness }\end{array}$ & $\begin{array}{c}\text { Mbility to shoot at targets / Importance of military fitness / Optimal body image / University need } \\
\text { for healthy forces / Readiness to carry casualties / Improve physical endurance in critical } \\
\text { situations / Increase physical fitness in combat }\end{array}$ \\
\hline
\end{tabular}


Table 3. Selective, Axial, and Open Coding of Contextual Conditions

\begin{tabular}{|c|c|}
\hline Category & Open Code \\
\hline \multicolumn{2}{|l|}{ Contextual conditions } \\
\hline $\begin{array}{l}\text { Management } \\
\text { factors }\end{array}$ & $\begin{array}{l}\text { Positive management attitude / Providing a suitable platform for employees by managers / The } \\
\text { importance of sports by managers / Presence of managers in sports venues /Changing the attitude of } \\
\text { the authorities from treatment to prevention /Managers believe in sports /Put exercise in the daily } \\
\text { schedule of employees }\end{array}$ \\
\hline Official documents & Rules and regulations / regulations of departments / specialization of instructions \\
\hline Structural factors & $\begin{array}{l}\text { Construction of a equipped gym / increasing the attractiveness of university gyms / beautifying the } \\
\text { gym / allocating a gym in university centers / using appropriate equipment in sports / providing } \\
\text { facilities in the workplace of staff / strengthening the hardware dimension }\end{array}$ \\
\hline $\begin{array}{l}\text { Socio-cultural } \\
\text { factorss }\end{array}$ & $\begin{array}{l}\text { Paying attention to the limitations of women / creating a culture of Sport for all / sedentary life / } \\
\text { adding sports to the household basket / promoting sports among the families of employees }\end{array}$ \\
\hline
\end{tabular}

Table 4. Selective, Axial, and Open Coding of Intervention Factor

\begin{tabular}{lr}
\hline Category & Open Code \\
\hline $\begin{array}{l}\text { Intervention conditions } \\
\text { advertising }\end{array}$ & $\begin{array}{c}\text { Promoting family Sport for all / Sports advertising in the Ministry of Health / Approval of senior } \\
\text { managers in the development of Sport for all / Advertising the bedrock factors of sports } \\
\text { development }\end{array}$ \\
Inhibitory factors & $\begin{array}{c}\text { Insignificance of sports among employees / inactive lifestyle / managers 'refusal to allow } \\
\text { employees to play sports / managers' indifference to sports / inappropriate management in gyms / } \\
\text { lack of Sport for all planning / lack of sports priority / lack of commitment of officials to Sport } \\
\text { for all / lack of inclination Managers of the clinical department to sports / limited university } \\
\text { facilities / lack of proper planning / lack of a comprehensive and strategic plan }\end{array}$ \\
\hline
\end{tabular}

Table 5. Selective, Axial, and Open Coding of Strategies Dimension

\begin{tabular}{|c|c|}
\hline Category & Open Code \\
\hline \multicolumn{2}{|l|}{ Strategies } \\
\hline Axial program & $\begin{array}{l}\text { Increase per capita sport in the Armed Forces / Permission of staff by managers / Managers' } \\
\text { mechanisms for departments / Program for staff families }\end{array}$ \\
\hline $\begin{array}{l}\text { Support and } \\
\text { motivation } \\
\text { programs }\end{array}$ & $\begin{array}{l}\text { Promotion on condition of physical fitness of employees / Donation of sportswear / Support of sports } \\
\text { officials / Increase of internal and external incentives / Motivational factors Increase of working hours } \\
\text { / Identification of employees' motivations / Giving leave to women / Giving overtime to men / } \\
\text { Incentive program For the person in charge of each department / reducing the cost of sports in case of } \\
\text { not doing sports / giving subsidies to athlete staff }\end{array}$ \\
\hline $\begin{array}{l}\text { Holding } \\
\text { competitions }\end{array}$ & $\begin{array}{c}\text { University Retirement Olympiad / Employees' Families Olympiad / Holding competitions among } \\
\text { employees / Holding sports Olympiads among employees }\end{array}$ \\
\hline $\begin{array}{l}\text { Promote an } \\
\text { active lifestyle }\end{array}$ & $\begin{array}{l}\text { Exercise is part of a healthy life / Promoting a healthy lifestyle / Family support in creating a healthy } \\
\text { life / Healthy eating in the family / Holding family hiking and mountaineering programs }\end{array}$ \\
\hline $\begin{array}{l}\text { Monitoring and } \\
\text { Evaluation }\end{array}$ & $\begin{array}{l}\text { Supervising the development of Sport for all / Supervising the president of the university on sports / } \\
\text { Team evaluation / Inter-sectoral evaluation at the university }\end{array}$ \\
\hline
\end{tabular}

Table 6. Selective, Axial, and Open Coding of Consequences

\begin{tabular}{lc}
\hline Category & Open Code \\
\hline Consequences & $\begin{array}{c}\text { Reduced treatment costs / High motivation at work / Increased organizational affiliation / } \\
\text { Increased focus on work / Increased work efficiency / System agility with Sport for all / High } \\
\text { efficiency / Quality of organizational performance / Increased quality of performance / Increased } \\
\text { social capital with Sport for all / Development Health force }\end{array}$ \\
Organizational & $\begin{array}{c}\text { Quality of individual performance / Creating enthusiasm in employees / Physical and mental } \\
\text { health / Increasing motivation / Creating good and effective communication between employees / } \\
\text { Preventing diseases / Reducing obesity / Increasing thinking power / Reducing motor poverty }\end{array}$ \\
\hline
\end{tabular}

Contextual Conditions. There are certain conditions that affect strategies. In this study, internal factors affecting the main phenomenon and strategies have been considered as contextual conditions.
Intervention conditions. There are general contextual conditions that influence strategies. Thus, in this section, general factors that influence strategies and the central 
phenomenon from the external environment were identified.

Strategies. Strategies are specific actions or interactions that result from a central phenomenon and are influenced by contextual and intervening conditions. Therefore, in this section, the strategies to solve the internal and external challenges of the development of participation in Sport for all are presented.
Consequences. Consequences are the output of applying strategies that were examined according to internal and external conditions. The following implications are expected to be obtained from the proposed strategies. The consequences were identified in three codes by formulating appropriate strategies to improve the level of employee participation with the aim of developing Sport for all.

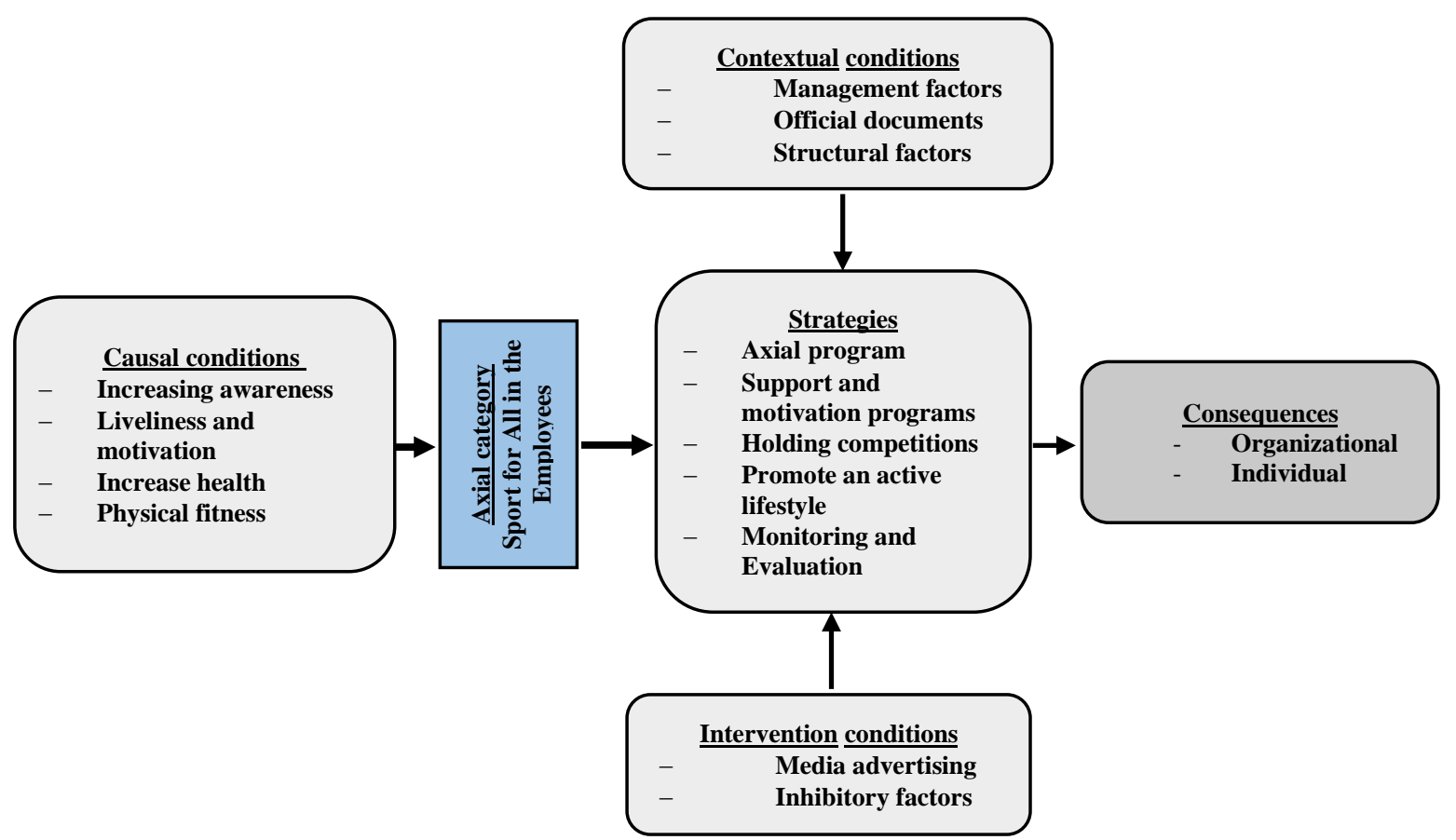

Figure 1. Axial Coding Paradigm of Factors for the Development of Sport for all of University Staff

\section{DISCUSSION}

According to the research results, one of the important factors in the development of Sport for all is to increase the knowledge and awareness of employees about the benefits of sports and to institutionalize Sport for all. Education and awareness will form a positive belief and attitude towards sports and physical activity. Increasing awareness through family support (19), and providing appropriate training programs to individuals about the positive effects of exercise, can be effective in raising the work capacity index of employees (20).Thus, improves the level of awareness and attitude of employees about the importance and benefits of sports activities and the harms of a sedentary lifestyle by informing them by sending motivational text messages, holding discussion sessions and teaching theory, preparing educational content based on health and sports, telephone follow-ups. It motivates people and encourages them to exercise regularly. Also, paying attention to the physical and mental health of employees is an important part of the effectiveness of participating in sports. Healthy organizations attach great importance to the exercise of their employees; because they know the vitality of employees in their sports activities. On the other hand, people want to participate in activities that are enjoyable, simple, and varied. Therefore, participation in Sport for all activities will increase if they are enjoyable in nature. Since the personnel of the Armed Forces constitutes a large number of people in the society and due to the importance of physical fitness of the military force, the university needs healthy forces, readiness to carry the wounded, improve physical endurance in critical situations and increase physical fitness in combat conditions - By presenting morning exercise programs in the units 
of this organization, a large part of the society can be directed to sports activities.

Also, one of the factors motivating employees to participate in sports is the support of managers and their presence in sports spaces and places (especially during conferences, competitions, and sports festivals), which can be done by formulating rules and regulations. Letters should be made more operational by the Ministry of Health, considering its key role in maintaining and promoting public health. Creating green spaces in the university to promote walking, construction of standard safe gyms and outdoor playgrounds are key factors in increasing the sports participation of university staff. The construction of these places should be planned according to the aesthetic features and the creation of new designs in order to make sports venues more attractive. The design of the environment and its aesthetics also make the sidewalks more attractive, cause healthy behavior that improves people's mental health, decreases stress, anxiety, and depression, and increases the rate of staff walking (21). The construction of bicycle stations, painting and marking of cyclists' routes are some of the ways to promote the use of active transportation. The existence of active transportation has been expressed as one of the effective factors in increasing people's participation in physical activities (22). Despite the many effects of sports, most university administrators do not have a positive view of it and even consider the development of sports as a waste of time. In their planning, the sport has a low priority or even is not a priority in some sectors (such as the clinical sector). Lack of trainers and mentors and lack of standard training (23), limited financial resources and low monthly income of staff and cost of sports programs (24) lack of facilities and equipment $(25,26))$ lack of sports facilities for staff, non-standard facilities Existing sports (27), physical disabilities or fear of sports injuries caused by sports activities all create negative perceptions of physical activity (28), low perception of health and devaluing it are among the most important factors preventing participation in Sports activities of university staff. However, the development of participation in Sport for all of university staff requires a central program in this area. These programs can be accompanied by the promotion of a healthy lifestyle, family support in creating a healthy life, increasing per capita sports in the armed forces, and holding family hiking and mountaineering programs. On the other hand, a fair incentive and reward system in the human resources sector will encourage them to perform better tasks and move towards predetermined goals. In-depth study and knowledge of managers about the physical condition of employees causes managers to apply regulations and supportive measures to lead employees to sports such as granting work leave to female employees, overtime to men and close monitoring and evaluation of performance supportive regulations and programs contribute to the health and wellbeing of employees through exercise (29).

According to the analysis of the interviews, one of the important consequences in the development of sport for all is organizational consequences. These consequences include reducing medical costs, high motivation at work, increasing organizational affiliation, increasing work focus, increasing work efficiency, system agility with Sport for all, high efficiency, quality of organizational performance, increasing quality of performance, increasing efficiency during service. Studies have shown that organizational policies are the supportive environment of the organization (30). Promoting health through physical activity in the workplace Special economic benefits such as reducing health care costs (31). Increasing productivity and efficiency has a healthier social and physical environment (5). Other consequences are individual factors. In the individual dimension, physical activity and exercise in the workplace are not only useful in promoting the personal physical and mental health of employees, but also have benefits such as reducing employee absenteeism (32). Evidence has shown that physical activity in the workplace can increase the number of other activities of employees such as walking (33) which is effective in reducing neck and upper back pain as well as cholesterol among employees and also improves mood such as stress due to overwork, stress, and fatigue (34).

\section{CONCLUSION}

In general, it can be said that training a healthy workforce requires the promotion and development of participation in Sport for all. Physical activity and participation in the Sport for all program of universities can also make a significant contribution to improving the level of public health of the university community, therefore recognizing the effective factors in the development of sport for all in the university can cause planners to be aware of them and take 
measures to make appropriate plans to remove barriers and create the necessary incentives for sports participation. Recognizing the motivational dimensions that affect people's sports behavior is a useful and fundamental step for people to participate effectively in sports activities.

\section{APPLICABLE REMARKS}

- Emphasizing the importance of sports activities by university administrators.

- Holding competitions and family festivals among employees.

\section{REFRENCES}

1. Guthold R, Stevens GA, Riley LM, Bull FC. Worldwide trends in insufficient physical activity from 2001 to 2016: a pooled analysis of 358 population-based surveys with 1. 9 million participants. Lancet Global Health. 2018;6(10):e1077-e1086. doi: 10.1016/S2214-109X(18)30357-7

2. Lee IM, Shiroma EJ, Lobelo F, Puska P, Blair SN, Katzmarzyk PT. Effect of physical inactivity on major non-communicable diseases worldwide: an analysis of burden of disease and life expectancy. Lancet. 2012;380(9838):219-229. doi: 10.1016/S0140-6736(12)61031-9

3. Butler CE, Clark BR, Burlis TL, Castillo JC, Racette SB. Physical Activity for Campus Employees: A University Worksite Wellness Program. J Phys Act Health. 2015;12(4):470-476. doi: 10.1123/jpah.2013-0185 pmid: 24905703

4. Bardus M. Theory of planned behaviour, participation, and physical activity communication in the workplace: Università Della Svizzera italiana2012.

5. Weiss R, Dziura J, Burgert TS, Tamborlane WV, Taksali SE, Yeckel CW, et al. Obesity and the metabolic syndrome in children and adolescents. $N$ Engl J Med. 2004;350(23):2362-2374. doi: 10.1056/NEJMoa031049 pmid: 15175438

6. Batt ME. Physical activity interventions in the workplace: the rationale and future direction for workplace wellness. Br J Sports Med. 2009;43(1):47-48. doi: 10.1136/bjsm.2008.053488 pmid: 18971246

7. Wiklund P. The role of physical activity and exercise in obesity and weight management: Time for critical appraisal. J Sport Health Sci. 2016;5(2):151-154. doi: 10.1016/j.jshs.2016.04.001 pmid: 30356545

8. Malm C, Jakobsson J, Isaksson A. Physical Activity and Sports-Real Health Benefits: A Review with Insight into the Public Health of Sweden. Sports (Basel). 2019;7(5). doi: 10.3390/sports7050127 pmid: 31126126

9. Rashidzadeh F. The nature and factors of spiritual excellence of the Armed Forces of the Islamic Republic of Iran. Secur Res J. 2013;12(44):7-27.

10. Ghafouri F, Honari H, Qaderi JA. Identifying the influential factors in the development of NAJA sports. J Resource Manage Law Enforcement. 2018;6(4):137-162.

11. Shahbazi M, Shabani Moghadam K, Saffari M. Public Sports (Necessity, Obstacles and Strategies). Quarter J Parliament Strategy. 2013;20(76).

12. Majdara A. Development in Public Sports, Public Sports Federation Publishing2018.

13. Adelkhani A, Vaezi SMK, Farahani A. Cultural Capital of Participants in Public Sports (Policies and Strategies). Quarter J Parliament Strategy. 2012;19(69):32-35.

14.George ES, Kolt GS, Rosenkranz RR, Guagliano JM. Physical activity and sedentary time: male perceptions in a university work environment. Am J Mens Health. 2014;8(2):148-158. doi: 10.1177/1557988313497217 pmid: 23966228

15. Mathews E, Lakshmi JK, Ravindran TK, Pratt M, Thankappan KR. Perceptions of barriers and facilitators in physical activity participation among women in Thiruvananthapuram City, India. Glob Health Promot. 2016;23(4):27-36. doi: 10.1177/1757975915573878 pmid: 25829405 
16. Bolotin AE, Bakayev VV, Moha AA, Chunguang Y. Sport Management Technology in Armed Forces Given Military Personnel's Physical Training Interests. Europe Proceed Soc Behav Sci. 2018;EpSBS(18th PCSF):1183-1190. doi: 10.15405/epsbs.2018.12.02.127

17. Derakhshan Mobarakeh M, Baran Cheshmeh MA, Ashtiani MR, Akbari Yazdi H. Codification of macro goals, policies and strategies for the development of physical education in the Armed Forces of the Islamic Republic of Iran. Defense Strategy Quarter. 2012;10(4):198-169.

18. Saadat Talab MB, Ghahraman Tabrizi K, Nouraei T. "Sports Needs in Military Training Centers from the Soldiers' Perspectives and Explaining Their Attitudes". Military Manage Quarter. 2015;57:59-81.

19. Gavin J, Mcbrearty M, Malo K, Abravanel M, Moudrakovski T. Adolescents' perception of the psychosocial factors affecting sustained engagement in sports and physical activity. Int J Exercise Sci. 2016;9(4):384.

20. Mendelson M, Borowik A, Michallet AS, Perrin C, Monneret D, Faure P, et al. Sleep quality, sleep duration and physical activity in obese adolescents: effects of exercise training. Pediatr Obes. 2016;11(1):26-32. doi: 10.1111/ijpo.12015 pmid: 25727885

21.Koohsari MJ, McCormack GR, Nakaya T, Shibata A, Ishii K, Yasunaga A, et al. Walking-friendly built environments and objectively measured physical function in older adults. J Sport Health Sci. 2020;9(6):651-656. doi: 10.1016/j.jshs.2020.02.002 pmid: 33308816

22. Fletcher GF, Landolfo C, Niebauer J, Ozemek C, Arena R, Lavie CJ. Reprint of: Promoting Physical Activity and Exercise: JACC Health Promotion Series. J Am Coll Cardiol. 2018;72(23 Pt B):3053-3070. doi: 10.1016/j.jacc.2018.10.025 pmid: 30522636

23. Cooper K, Barton GC. An exploration of physical activity and wellbeing in university employees. Perspect Public Health. 2016;136(3):152-160. doi: 10.1177/1757913915593103 pmid: 26194136

24.Peloquin C, Doering T, Alley S, Rebar A. The facilitators and barriers of physical activity among Aboriginal and Torres Strait Islander regional sport participants. Aust $N$ Z J Public Health. 2017;41(5):474-479. doi: 10.1111/1753-6405.12701 pmid: 28749566

25. Chiu LKMMY, Mohd Sofian Omar F, Ahmad Tajuddin O, Mohd Salleh A, Gunathevan E, Hamdan MA. Examining Sport and Physical Activity Participation, Motivations and Barriers among Young Malaysians. Asian Soc Sci. 2016;12(1):159-171. doi: 10.5539/ass.v12n1p159

26.Edmunds S, Hurst L, Harvey K. Physical activity barriers in the workplace. Int J Workplace Health Manage. 2013;23. doi: 10.1108/IJWHM-11-2010-0040

27.Jaarsma EA, Dijkstra PU, Geertzen JH, Dekker R. Barriers to and facilitators of sports participation for people with physical disabilities: a systematic review. Scand J Med Sci Sports. 2014;24(6):871-881. doi: 10.1111/sms. 12218 pmid: 24730752

28. Hunter JR, Gordon BA, Bird SR, Benson AC. Perceived barriers and facilitators to workplace exercise participation. Int J Workplace Health Manage. 2018. doi: 10.1108/IJWHM-04-2018-0055

29. Boutevillain L, Dupeyron A, Rouch C, Richard E, Coudeyre E. Facilitators and barriers to physical activity in people with chronic low back pain: A qualitative study. PLoS One. 2017;12(7):e0179826. doi: 10.1371/journal.pone.0179826 pmid: 28742820

30. Bale JM, Gazmararian JA, Elon L. Effect of the Work Environment on Using Time at Work to Exercise. AM J Health Promot? 2014;12.

31.Finkelstein E, Fiebelkorn $1 \mathrm{C}$, Wang G. The costs of obesity among full-time employees. Am J Health Promot. 2005;20(1):45-51. doi: 10.4278/0890-1171-20.1.45 pmid: 16171161

32.Rose G. Sick individuals and sick populations. Int J Epidemiol. 2001;30(3):427-432; discussion 433424. doi: 10.1093/ije/30.3.427 pmid: 11416056

33. Shilton T, Sparks M, McQueen D, Lamarre MC, Jackson S, executive committee of the International Union for Health $\mathrm{P}$, et al. Proposal for new definition of health. BMJ. 2011;343:d5359. doi: 10.1136/bmj.d5359 pmid: 21862543

34.Last JM. A dictionary of public health. Oxford: Oxford University Press2007. 